differentiation of these implements, and from this has inferred a difference in racial origin.

\section{The Cable Repair Ship H.M.T.S. Monarch}

IN connexion with 'Telephone Week' (October 1-6), members of the general public had an opportunity of inspecting the Post Office cable repair ship Monarch, which was lying in the Thames off the Tower. This ship is fitted out with the special gear necessary for carrying out all the operations required in cable laying and repair, on which service she is at sea for most of the year attending to cables such as those laid between Great Britain and the Continent. The positions of cables are charted so that a faulty section or broken cable may be located and raised by means of grappling gear, of which there are various types provided. The ship's testing laboratory contains apparatus for the measurement of conductor resistance, insulation resistance, localisation of faults and other tests applied to the end of a cable which has been hauled on board. Sections of defective cables are replaced by lengths of new cable, a supply of which is carried in the ship, and the repaired cable relaid and charted, a somewhat noticeable feature of the cross Channel cables being the large number of repairs marked on the charts. The ship is provided with wireless equipment including a valve transmitter and, in reserve, a quenched-spark transmitter. In addition to an ordinary receiver there are a directional receiver and an emergency automatic call whioh rings an alarm bell, when the operator is not on watch, as soon as it responds to three 'Iongs', of four seconds duration, out of the twelve sent for the S O S signal. The chart house contains an echo sounding device. The ship's complement is 14 officers and 50 ratings, this large number being required on account of the technical duties, in addition to ordinary duties, carried out on board.

\section{Telephone Statistics of the World}

IN Electrical Communication of July the telephone and telegraph statistics of the world have been published up to January 1933. The United States have now 53 per cent of the total number of telephones in use in the world, Canada has 4 per cent, Germany 9 per cent, Great Britain $6 \cdot 5$ per cent, France 4 per cent, the remaining European countries 14 per cent and all other countries 9 per cent. In January 1928, the United States had 60 per. cent and Europe 28 per cent as compared with 33.5 per cent now. Whilst the number of telephones in Europe has increased by about 20 per cent during those five years, the number in the United States has diminished by 12 per cent. San Francisco leads the world with $36 \cdot 5$ telephones per 100 of the population and Washington comes next with $33 \cdot 3$. Stockholm is third with 31.8. In Canada, Toronto has $25 \cdot 6$ and Vancouver 28.1. Paris has 15, Berlin $11 \cdot 1$ and Munich 10. London heads the cities in Great Britain with 8.8 and Edinburgh comes next with 6.9. Honolulu, with a population of 138,000 , has $11 \cdot 7$ telephones per 100. Whilst the United States have 70 miles of telephone wire per 100 of the population, Canada has 48, Australia and New Zealand 39, Sweden has
$32 \cdot 7$ and Denmark $31 \cdot 5$. Germany has $23 \cdot 2$, Great Britain and Northern Ireland $22 \cdot 6$ and France $10 \cdot 7$. India and China have only 0.11 miles of telephone wire per 100 of the population. Czechoslovakia, the United States and New Zealand use their telephones more than other countries. The telephone conversations per capita in these three countries in 1932 were $224 \cdot 5,204 \cdot 6$ and $205 \cdot 8$ respectively. This compares with 33 in Britain and Germany and 20.5 in France. The number of conversations by telephone now averages about 100 times as many as of communications sent by telegraph.

\section{Social Sciences in the United States}

THE social sciences and, especially, applied social science or civics, figure prominently in discussions of current educational policies in the United States, as witness the monthly Educational Review published as a supplement to School and Society of July 7. An advanced school of thought has lately found an exponent in Richard Welling, whose "Civics as it should be taught" has provoked discussion about the courage needed by teachers to teach "the real facts about distorted democracy", and led to a proposal to form a union to teach civic truth and to protect anyone who does it. A new monthly journal of educational criticism and reconstruction is to appear this month under the name of the Social Frontier (2 dollars annually, 66 West 88th Street, New York) to be devoted to "serving the emerging consciousness among American teachers that they must participate fully in social processes reshaping the American order". The report of the American Historical Association's commission on the social studies has, after repeated revisions, reached its final form, a compromise between conflicting views (New York: Charles Scribner's Sons. 170 pp., 1.25 dollars). It calls for increased emphasis on social instruction from the kindergarten upward and extending to the adult population, and it stresses the need for a more realistic approach with frequent interpolation of the question: How is it in your own town, city, country? The principal article in the same issue, entitled "Cultural Objectives of Health Education" by the professor of public health, Yale School of Medicine, urges that teachers should bear in mind that they are educating citizens and not merely doctors or lawyers or farmers, or stenographers or salesmen or bank presidents.

\section{Research in Industrial Health}

THE fourteenth annual report of the Industrial Health Research Board up to June 30 emphasises, as have previous reports, that, "the study of the physiology and psychology of the worker is to reveal as many problems as are solved : to the fundamental problems becomes added that of overcoming difficulties in methods of approach and in technique". Trustworthy data about the incidence and kind of ill-health from which the workers in different occupa. tions suffer are a pressing need. In the introduction to the report is a discussion of some of the difficulties in the way of obtaining data. An account of the chief problems now being investigated is given in outline. 